\title{
Ras-Related C3 Botulinum Toxin Substrate 3
}

National Cancer Institute

\section{Source}

National Cancer Institute. Ras-Related C3 Botulinum Toxin Substrate 3. NCI Thesaurus.

Code C104819.

Ras-related C3 botulinum toxin substrate 3 (192 aa, $21 \mathrm{kDa}$ ) is encoded by the human RAC3 gene. This protein is involved in the formation of lamellipodia and membrane ruffles. 